\title{
EFFECT OF EFFECTIVE COMMUNICATION AND SOFT SKILL TRAINING ON KNOWLEDGE IMPROVEMENT AMONG NURSES
}

\author{
Rita Kartika Sari'), Livana PH' ${ }^{2)}$, Muh Ali3) \\ 1)Faculty of Medicine, Universitas Islam Sultan Agung, Semarang \\ ${ }^{2)}$ Study Program in Nursing, School of Health Sciences, Kendal \\ 3)Jepara Kartini Regional General Hospital
}

\begin{abstract}
Background: Nurses work in a fast-paced technical environment. They must make quick decisions about patient care and effectively communicate with other healthcare personnel. Training on nurses is needed to enhance the effectiveness of in-service training of nurses. This study aimed to determine the effect of effective communication and soft skill training on knowledge improvement among nurses.

Subjects and Method: This study was a quasi-experimental with pre-test and post-test without control group design. This study was conducted at Sultan Hadlirin Hospital, Jepara. A sample of 116 nurses was selected purposively. The dependent variable was knowledge improvement. The independent variable was effective communication and soft skill training. The data were collected by questionnaire and tested by chi-square.

Results: Nurses' knowledge improved after the communication and soft skill training, and it was statistically significant $(\mathrm{p}=0.027)$.

Conclusion: The communication and soft skill training is effective to improve nurses' knowledge.
\end{abstract}

Keywords: training, communication, soft skill, nurse, knowledge

Correspondence:

Rita Kartika Sari. Faculty of Medicine, Universitas Islam Sultan Agung, Semarang, Central Java. Email: rita.kartika.sari@gmail.com. Mobile: 082225934333.

The $5^{\text {th }}$ International Conference on Public Health Best Western Premier Hotel, Solo, Indonesia, February 13-14, 2019 | 231 https://doi.org/10.26911/theicph.2019.02.41 